\title{
Economic Crisis and the Extroversion of the Enterprises: An Empirical Approach
}

\author{
Dr. G. M. Aspridis
}

Assistant Professor, Department of Project Management, Technological Educational Institute of Thessaly. aspridis@teilar.gr

\section{Dr. L. Sdrolias}

Associate Professor, Department of Project Management, Technological Educational Institute of Thessaly. Isdrolias@teilar.gr

Dr. N. Blanas

Associate Professor, Department of Project Management, Technological Educational Institute of Thessaly. nikoblan@teilar.gr

\section{Kyriakou}

BSc, MBA, MSc, dimk21@gmail.com

\section{Grigoriou}

BSc, MBA Candidate, ioangri@yahoo.gr

Doi:10.5901/ajis.2013.v2n9p696

\begin{abstract}
In recent years, due to the economic crisis there is the phenomenon of diminishing the consumption within the limits of the country. Companies are looking for alternative ways to maintain and/or increase their profits. For this reason many of them are turning to exports, with which, it has been proved that Greeks can be productive and competitive. The extroversion of businesses aimed at the beginning or even the continuation of competitiveness and their business activity abroad. Thanks to extroversion, production relocates in industries and higher value-added products and contributes to the conclusion of international collaborations. It also increases the visibility of Greek enterprises and their products abroad, international cooperation and finally it stimulates entrepreneurship in times of crisis. Such companies, which invest in extroversion in times of crisis, is the Folli-Follie, with large investments in China, the cooperative of Naoussa Vaeni winemakers, who works with Chinese trading company. Also, Kozani Saffron and the company Fereikos-Helix, which deals with the breeding of snails Helix Aspers Moller. All of these efforts are reinforced by the program "Extroversion - business competitiveness (2007 - 2013)". In this study we will try to develop the sequel (;) economic development and answer questions such as: what was the situation in the area of exports before the economic crisis, what is the existing situation and finally what are the future opportunities for Greek companies. The conclusions of this study are particularly important and any exploitation will contribute substantially to increasing openness and hope to be the beginning for conducting future surveys.
\end{abstract}

Keywords : Extroversion, entrepreneurship, export, trade, technology, competitiveness

\section{Introduction}

Strengthening the extroversion is a one way to development both for businesses and the economy of the state. Besides referring to the theory of Ricardo "if each nation specializes in the production of goods for which a class has a comparative cost advantage and then exchanges with another nation, which has a cost advantage over another category 
of goods, then there will be a total commercial profit and at the same time will increase the total income in both countries" (Anggelopoulos, 2007).

In times of crisis the extroversion is the keyword for the development of Greek enterprises. Especially for those businesses who believe that the crisis can be an opportunity to grow. The "solution" of extroversion is adopting more and more for the new model of development of Greece. Economists and entrepreneurs consider that emphasis should be placed on foreign markets, domestic companies to export their goods and services and, most importantly, introduce investment funds. And of course this way we avoid mergers or/and the closure of companies. Greece should stop being the most closed market in relation to the other Member States participating in the euro.

The research will mainly rely on the study of existing literature and case studies from the Greek experience, so to prove or not the contribution of the extroversion of Greek businesses in dealing with the crisis. Through these methods we will try to answer some questions such as whether there is continuity (;) economic growth, which was the situation in the area of exports before the economic crisis, what the existing situation is and finally what are the future opportunities for Greek companies?

\section{Literature review}

Extroversion, as a concept, derived from the field of psychology and an indication of the psychological nature of man. Jung distinguishes two stances, extroversion and introversion, which affect mental processes and call this the mood "Central Control Panel, from which external behavior is adjusting and on the other hand concrete experiences are shaped". Extroversion is characterized by a positive relationship with the subject and introversion from a negative. The extroverted geared primarily from external, collective rules, the spirit of the season, and more. The Extrovert "thinks, feels and acts in connection with the subject". Shifts his interest from the object to subject and directs mainly by the world outside himself (Fordham, ).

The original use of extroversion was as a political term, and recently began to be used, in order to express the process of economic integration of a country and mainly here in Greece, with world markets. The main activities include international trade in goods and services, the international portfolio investments and foreign direct investments. The degree of openness of a country depends on several factors, including the importance of international trade, the trading quality and other (Chletsos, 2008). The extroverted activities essentially refer to business activities of individuals, businesses or organizations that transcend national borders and extend to other countries (http://repository.edulll.gr ledulll/retrieve/4619/1315.pdf).

The Extroversion is the exploitation of competitive advantages and circumstances and at the same time, the expansion of businesses (small and large) to new markets outside our national borders. To achieve this, it is necessary to establish both a healthy indoor environment and an outside environment ready to accept our products (Ioannidis, 2007). Extroversion expresses the framework of liberalization and openness of international markets and the development of international business activities by national companies. These activities relate to business activities, companies and/or individuals that transcend national borders and extend to other countries. Extroversion is intertwined with the concept of competitiveness, facilitates entrepreneurship and creates new opportunities. In times of crisis, the private sector must lead and radically change its orientation, focusing on exports, something that becomes a priority due to the negative impact of the economic crisis on corporate earnings and consumption (Stergiou, 2007; loannidis, 2007).

The degree of openness of a country depends on the importance of international trade in relation to national transactions (volume of international/national transactions), the type of integration (in the areas of trade in goods and services and investment) as well as the quality of transactions (value added) (Dunning, 1993). Also, it refers to commercial activity which aims to export goods and services, the sale abroad.

As competitiveness (Chletsos, 2008) we define the ability of a business to survive and develop, taking into account the competition from other companies for the same profits. Businesses compete for markets and resources and therefore it is relatively easy to look, comparatively, at their competitive position purchasing shares of markets or the extension of setting up and building-up competitive advantages such as sanitary products, innovation processes (Pournarakis et al, 2011).

\section{The Greek Economy}

The main sectors of the Greek economy are tourism, shipping, industrial food production and tobacco processing, textiles, chemicals, metal products, mining and petroleum refining units. The growth of Greece's GDP is, on average, since 1990, higher than the average of EU countries. The Greek economy also faces significant problems, including rising 
unemployment levels, bureaucracy and corruption. In 2009, Greece had the second lowest rank in the EU in accordance with the index of economic freedom (after Poland), while ranked 81st in the world. The country suffers from high levels of political and economic corruption and low competitiveness compared to its European partners.

Due to the global economic crisis, the pace of growth of the economy turned negative in 2009 for the first time since 1993. By the end of 2009, as a result of a combination of international financial crisis and internal factors (uncontrolled waste shortly before elections in October 2009), the Greek economy faced its most serious crisis since 1993, with the highest public deficit (although close to that of Ireland and the United Kingdom) as well as the second highest debt as a percentage of the EU GDP. The 2009 budget deficit reached 15.4 percent of GDP. This and the rising debt levels (127.1\% of GDP in 2009) led to rising borrowing costs, resulting in a severe economic crisis. Greece tries to cover the excessive public deficit in the wake of the global financial crisis.

On January 1st 2002 Euro was introduced in EU. It turned out that its success depends on healthy and sustainable financial management and strong macroeconomic policies. The base for recovery is strengthened further through the "Financial Contract" agreed by EU leaders in the pursuit of budgetary discipline and increased coordination and economic policy throughout the euro area (EU, 2012).

Important resources pumped through 4 community initiatives, total public spending which amounts to $€ 1.28$ billion (of which the Community contribution is $904 \mathrm{~m} €$ ) for the period 2000-2006. The four Community initiatives of the European structural funds for the period 2000-2006 is EQUAL (equality in the labor market), LEADER+ (rural development), URBAN II (urban development) and INTERREG III (cross-border, transnational, interregional cooperation). The Cohesion Fund provides co-funding to projects or groups of projects or stages of projects which contribute to the achievement of the objectives in the area of "environment" and "Transport".

The NSRF 2007-2013 is the reference document for the programming of EU Funds at national level for the period 2007-2013. Prepared in the context of the new strategic approach for the EU cohesion policy, whereby the NSRF "ensures that assistance from the funds is consistent with the Community strategic guidelines for cohesion and identifies the link between Community priorities, on the one hand, and of the national reform program, on the other hand". The objectives of the NSRF was formulated at the level of the strategic objectives of the NSRF, the level of thematic and territorial priorities, as required by the General Regulation on the Funds, at the level of general objectives, which breaks down each thematic priority and finally at the level of the specific objectives and the main means to achieve.

The architecture of the Operational Programs (OP) of the NSRF 2007-2013 was shaped so as to materialize with the optimal way the country's strategic options, while taking into account the new data in the programming period 20072013 (63\% of the country's population in transitional support). The new shape is characterized by a smaller number of operational programs in relation to the previous period 2000-2006, which leads to more flexible management scheme. Strategic planning for the period 2007 - 2013 will be implemented through 8 sectoral OP, 5 regional OP and 14 European territorial cooperation programs. In the period 2007 - 2013 the total accessibility infrastructures will be implemented in the framework of sectoral operational program, while for the areas of health and culture there will no longer be a discrete Op and actions implemented by regional and sectoral operational program.

The medium-long term prolongation of the recession in the Greek economy with negative or low rates of GDP change, risks the increasing of public debt and therefore requires not only the reduction of public deficits but creating primary surpluses that will gradually stabilize the public debt as a percentage of GDP. It is necessary to follow policies that will increase the tax revenue reasonably $\neg$ (capture of great tax evasion, tax increase on high earners and the great real estate) and transfer of resources from public consumption to public and private investment in priority areas and proliferative effect. It is necessary to design and implement new strategies for economic growth by adopting a new development model that will focus on technology, innovation, quality and will create new jobs (INE - GSEE, 2010; Sklias et al, 2010).

\section{Extroversion : The Silent Force ${ }^{1}$}

Greece presented intense commotion to the piece of extroversion. The period from 2004 to the beginning of the crisis was the golden period of exports. A coordinated policy on exports was formed and that was the last standard product. In that period, our country has participated in numerous international exhibitions; several business missions were completed and opened the market to other economies such as Korea, the United Arab Emirates and other (Drosos, 2006). 
According to the NSS, the increase in exports in the first three years of the period stood at $34.4 \%$ with the main strategy targeting the larger international markets, to increase the participation of enterprises in concerted actions and effective support for our products (Drosos, 2007).

In 2011 the total value of Greek exports amounted to approximately 19.5 billion $€$ (excluding sales of ships). Exports registered a significant increase of their volume, rate of 19.6\%. The main volume and value of exports are fruits, vegetables, olive oil, textiles, steel, aluminum, cement and various manufacturing products. The increase of competitiveness as a result of lower prices of products and productive players in Greece, as a result of the domestic economic crisis played important role. In January 2012, the value of exports stood at 1.75 billion $€$ (http://www.bmssa.gr/ellhninkh-exwstrefeia.aspx.

The extroversion of Greek economy is dynamic and is considered to be capable to provide itself the driving force for development in Greece. Especially if the right incentives are given and appropriate infrastructure is been built, mainly electronic. For the development of the extroversion of enterprises, Secretary of the Ministry of Development, Industry, Competitiveness and Shipping modeled the program "Extroversion - Competitiveness II" with a budget of EUR 50 million. $€$, which is co-funded by the EU through the European regional development fund and the Greek State and is part of the operational program "Competitiveness and entrepreneurship" of ESPA 2007-2013 (http://www.antagonistikotita.gr/ greek/news. .asp?id=326).

The aim of the program is the creation of conditions for strengthening Extrovert entrepreneurship existing manufacturing, mainly for small and medium-sized enterprises, and conditioned big business, as the Central choice for production upgrading of the economy for goods and services with a high added value, quality, environmental awareness, knowledge integration and innovation. In addition, it focuses on strengthening of integrated investment projects with emphasis on processing activities with conjugation activities outreach and visibility in international markets, in order to ensure the achievement of multiplicative benefits and economies of scale (http://www.antagonistikotita.gr /greek/news. asp?id=326).

The investment projects aim to enhance the extroversion of businesses including limited processing operations, investment projects aimed at strengthening Extrovert image and business activity coupled with actions (http://www.antagonistikotita.gr/greek/news.asp?id=326, www.ypoian.gr, www.antagonistikotita.gr, www.efepae.gr, www.espa.gr, www.ependyseis.gr/mis, www.ggb.gr). The Export Credit Insurance Organization (ECIO), implemented the program "Extroversion - ECIO" which was a demand of the country's export businesses, and offered a shot in the arm in the real economy and substantive support to the extrovert entrepreneurship. At the same time, it strengthened the competitiveness and flexibility of Greek exporting companies. The program ensured the possibility of financing of export operations, the sole prerequisite their insurance to $\mathrm{EClO}$

In early February 2012, it was announced by the General Secretariat for industry the new EU program for small and medium-sized enterprises, the "Program for the Competitiveness of enterprises and small and medium-sized enterprises-COSME" (http://www.ggb.gr)

The objective is the development of Greek positions in view of negotiation to be launched within the Council of the EU. The main axes of the improvement of the competitiveness and the viability of EU companies, the promotion of entrepreneurship in specific target groups, improving access to finance for SMEs, in the form of risk capital, guarantees, loans and the improvement of access to markets within the EU and globally. 38.7\% of export businesses exhibit intense liquidity problems have gone to cuts and difficulties in accessing new lines of financing. Also $15.4 \%$ of companies operating on the international markets in 2009 (almost 1 in 7 export businesses) have shut down or stop the export activity.

\section{Examples of extrovert enterprises}

In this presentation we will confine ourselves to four companies. We will not mention enterprises of metallurgical industry ${ }^{2}$, as the Group Biohalco, Alumil and Titan, because although starring in exports, they do not have any particular product of Greece. Nor do we mention food companies such as FAGE ${ }^{3}$ or water bottlers, such as Chittos. We will go to companies with strong brand name as is the Folli Follie or in companies which produce and market a particular product of the Greek land, such as saffron, snail farmers and businesses that produce and sell wine, that have to do with the

${ }^{2}$ The S\&B industrial mineral has 26 distribution centers in 21 countries and acquisitions in the U.S

${ }^{3}$ For example, the dairy industry KRI-KRI, who is ejecting in more than 15 countries. 
primary sector of the Greek economy, in line with the Minister of Macedonia-Thrace, Karaoglou in his speech at the SEVE (July 2012).

\subsection{Folli Follie Group}

The Group has been present in 28 countries of the world, has 750 points of sale worldwide and employs around 6,000 workers. By the early 21st century, the Group invested abroad and particularly in China, in partnership with Fosun. In this way it faces the current recession. In 2010 sales increased by $8 \%$, due to exports. It is characteristic that over $95 \%$ of its sales made abroad, especially in Asia (Newsletter, 2011). G. Koutsolioutsos, Vice President of Folli Follie, considers that the only defense to deal with the recession is extroversion. Therefore the company has the largest part of its revenue from Japan and Asia, areas that this year's nine months contributed $11 \%$ and $62 \%$, respectively, in sales, with the second to record annual growth of around $18 \%$. The management of the company plans to develop its network in Asian markets but also in the U.S. Folli Follie Group is a model in terms of the image of a Greek business abroad. In China where it already maintained a network of 250 points, in partnership with Fosun there is a new opening every week. Finally, it is characteristic that in $\mathbf{2 0 1 0}$ the share of Folli Follie was one of the two shares of mid-caps of the ASE ended with about $40 \%$ profit (http://www.dealnews.gr).

\subsection{Cooperative of Winemakers of Naoussa, Vaeni.}

The cooperative of Naoussa Vaeni winemakers has completed an agreement with China to sell each year than 1.200.000 3.600.000 bottles to wine. It's the largest transnational agreement between Greece and China in exporting wine. The agreement covers the export of 300 containers of wine annually and for a decade, worth 10 million€ per year. With the completion of the agreement an order worth $€ 500,000$, which in its entirety deals more expensive wines of partnership and sponsorship cheque of $€ 350,000$ for the execution of orders, was already given. The cooperative exports its products in 27 countries, including Russia, China and the United States (http://cluster/www.palo.gr/articles/makedomnianews/27650/?=3197913? http://www.keosoe.gr/ampeli/deltia.html). In 2011 the cooperative managed to increase its exports by $120 \%$. The cooperative has a presence in a total of 27 countries. The aim is to find distribution channels in other countries, especially in emerging markets, since Vaeni's presence in Europe is already strong. (http://www.paseges.gr/el/news/120-ayxhsh-stis-exagwges-krasioy-apo-to-Synetaiirsmo-Vaeni-Naoysa).

According to Mr. Fountouli (2012), President of the Association "the policy of openness which was followed by the cooperative in the last years, the search for new markets abroad, as well as the complete shift to quality bottled products, upgrading Vaeni's brand name, provided domestic and international visibility and today this strategy yielded results far greater than expected. We do the Extroversion Act'. (http://www.maknews.gr)

\subsection{Saffron}

The variety of Crocus sativus $L$, thrives only in the certain area and belongs to the best quality saffron in the world (with its healing properties). The product is available in several countries, such as Spain, France, Italy, USA, Switzerland, England, Germany, the Scandinavian and Netherlands, UAE, Russia and Japan. At the same time, has made a business arrangement with the largest spice company in the world the Mc Cormick (http://www.safran.gr/trading.asp). It also achieved commercial agreement with Korres and established the company "Crocus Kozanis Products SA" with the aim of creating products based on the Saffron.(http://www.pta-pdm-smartplus.gr/assets/profile-innofin-anko.pdf). Exports account for $30 \%$ of sales to have fallen due to the global economic crisis. This resulted in growers to resume cultivation of crocus, with large profit margins. We mention that at the end of the last century Kozani produced 12 tons of saffron. The period 2002-2005, production was reduced to the minimum. For better coordination of activities, since 1971, the Kozani Cooperative of Saffron producers, was founded.

\subsection{Fereikos-Helix}

Maria and Panagiota Vlachou, began snail farming in an area of three acres and then expanded their business. For example they took the delegation of the International Institute for breeding snails all over Greece. Farmers began to replace their traditional crops with the rearing of snails, because the price is steadily upward (http://antikleidi.wordpress.com). 
Fereikos-Helix is headquartered in Corinth and started in 2007. It's creating open integrated life-cycle units of snail breeding. The company name derives from the ancient Greek word "fereoikos" which comes from the 'fetch' and 'House' and means 'I carry my house" (http://news.kathimerini.gr/4dcgi/ w articles_economyepix 100012_04/12/2011_464956). With the increase of turnover to exceed $6 \%$, within a period of three years, and the cooperating producers to arrive from 20 in 2008, to 155, Fereikos-Helix, extract snails, and relies on innovation. At the same time it shows that the return to primary production and extroversion are the successful model of modern entrepreneurship, amid crisis. Snails are a financial product whose value has not subsided, since 1972 until today. In contrast, the average annual price increase is of the order of 2\%-3\% (http://boraeinai.blogspot.gr/2011/12/e_08.html).

\section{Review}

The average cost required for export of products from our country formed in 1,153 dollars compared with 1,043 in the EU, while the time needed for completion of the process appreciated in 20 days against 11,71 days in the EU with a number of accompanying documents 5 against 4. For the imports of goods the cost is $\$ 1,420$ compared to $1.097,64$ in other European with required time 25 days against 12.35 and with necessary documents 6 vs. 5.35 . And in this area Greece is behind in relation to the EU and the internationalisation of SMEs and strengthening international partnerships is essential. The I.O.B.E Report on entrepreneurship in Greece 2010-2011 (Ioannidis et al, 2012) and the impact on "small business" reflects that the deterioration in economic conditions and the uncertainty about the outcome of the financial crisis influenced decisively the business action. In more detail, the results for home entrepreneurship subside noticeably and underscore the climate of uncertainty that prevails in the real economy. Entrepreneurship of "initial stages" arrives at the lowest rate for five years (5.3\% from $8.8 \%$ in 2009), with the aspiring entrepreneurs to be the main cause of the drop (2.0\% versus $4.5 \%$ in 2009). The report shows that adverse economic conditions and uncertainty about the future prevented a significant percentage of people to start their business.

The model of development, in accordance with the conclusions of the symposium organized by the Foundation for Mediterranean Studies (2008), has serious drawbacks as that absent a friendly and efficient institutional environment (whatever progress has noted the last time) and the organizational and management capacity, the low quality and flexibility of the educational system, the lack of modern infrastructure and networks; the low spending on research and innovation, low productivity, private, family and public debt, environmental degradation, high level corruption and customer relationships, high rate of poverty and social exclusion, the lack of democracy and effectiveness in our country and finally the institutions, structures and functions of our political system is, to a large extent, outdated, dysfunctional and ineffective.

There are needed changes, such as :

i. Radical structural and structural reforms (changes in e-governance, integrated information systems, cadastre, lucidity, rebuilding public sector, reduction of the public sector, fight corruption, exploitation of tax policy, improvement of education). ${ }^{4}$

ii. Coding, simplification and modernization of existing legislation, the fight against bureaucracy, interweaving, corruption and tackling patronage and black political money are required.

iii. The modernization of the legal system, strengthen of the integrity, and speeding up of procedures for the award of (Balyrakis, 2008).

The other view holds that extroversion leads to impoverishment of human potential of the country and the abolition of labour relations and workers' rights and simply supports businesses faced serious financial problems. According to Al. Papariga, ex leader of the greek communist party "extroversion does not apply to the mutual benefit of the peoples, but the competition of capital, operating and Greeks and foreign workers. We seek the full potential of Greece and at the same time the development of equitable international relations" (interview in Tupos tis Kyriakis, cited in Rizospastis 24/3/2009).

4President Rousvelt reshaped the American economy with a series of laws as was the implementation of new, stricter institutional framework for the banking system, lowered the high American interest rates, implemented new financial policy and monetary policy. Created the Rural Adjustment Administration, which put limit to the national production of agricultural products (http://tvxs.gr/news) 


\section{Suggestions}

The only reliable source for real growth of the economy is recovery of foreign demand for goods, thereby attracting new investment. The contribution of exports to GDP in 2012 reaches the level of 12\%, double than in 2010. Discern that more and more people realize the new model of extroversion of Greek economy but no one can really do it. The geographical export expansion of Greek products, especially to emerging markets, shows that the future is there (http://www.olakala.gr/oikonomia/2269-i-politimi-axia-tis-exostrefeias.html).

The Greek economy must be transformed rapidly into an environment of Extrovert mindsets, minimum bureaucracy, low taxation, low liquidity, competitive production, serious state aid, implementation of innovations, attracting new investments with a clear brand name. Greek economy can be a source of goods or services, innovative and traditional, for the global community. With a will, a clear strategy and immediate actions may become the hopeful reality (http://www.olakala.gr/oikonomia/2269-i-politimi-axia-tis-exostrefeias.html).

According to D. Lakasa, President of the Association of exporters of Northern Greece "the new country's development model with emphasis on Greek production and extroversion is the sound pillar for an economy that is trying to revive growth. With these data, a framework of coherent actions, from the production to the targeted permanent presence of Greek products and services at international level, in a national, powerful Brand Name, is required" (http://www.olakala.gr/oikonomia/2269-i-politimi-axia-tis-exostrefeias.html).

In the actions that must follow an extroverted Enterprises include the construction of foreign language Web Pages with specific standards, the construction and management of the e-shop for sales abroad, creating innovative electronic tools for collaboration with foreign enterprises, the creation and management of online shops and advanced interactive web sites via the Internet, the creation of advanced and innovative customer service systems and the concept of "do it yourself" and last but not least the acquisition of new equipment advanced technology for production of innovative products/services or implementing innovative processes, conduct online surveys/studies and evaluation of the export capacity and the access information for the online search and identify international business opportunities (http://espa.com.gr/protasei_exostrefeias/).

The demands of business is considered to be the ideal initiative on the way out of the country from the crisis and the limited potential for growth that characterizes the Greek market and especially in the age of globalization. We have, namely, to get away from the traditions and our nationalism which sometimes distinguish (Stergiou, 2007).

The Erasmus program can and should be a factor in the openness for Greek companies. The purpose of the program is to acquire professional experience and acquaintance with the requirements of the European market. According to the Commissioner of the European Commissioner for Education, Culture, Multilingualism and Youth Vasiliou "exchanges through Erasmus offer the opportunity to students to develop skills such as adaptability, which, in turn, enhance their professional prospects. Studies or internship abroad open up horizons for personal development and create employment opportunities". (http://europa.eu/rapid/pressReleasesAction.do?reference=IP/11/675\&format=HTML \&aged $=0$ \&language $=E L$, accessed on 28/8/2012).

Student mobility contributes to the personal development and the development of social skills, labor mobility and new ideas for businesses. Offers specialized knowledge, knowledge of foreign languages and development of existing competences and skills. Students are looking for new markets, extroversion is widening and the image of the company is modernized. (Mavrogiwrgou, 2012? http://compus.uom.gr/erasmus/?q=el/general, was on 13/8/2012). For young people thei participation in the Erasmus program gives them the opportunity to show off their skills, to consolidate scientific knowledge, develop professional consciousness and get to know new cultures. The institutions produce and promote research and innovation, showcasing an intense extroversion (Damoulianou, 2012).

During the $3^{\text {rd }}$ Hellenic Republic several developmental laws have voted on (Laws 1264/1982, 1892/1990, 2601/1998, 3299/2004 and 3522/2006). L. 3908/2011 "Private enterprises for economic growth, entrepreneurship and regional cohesion" (Official Newspaper of Greek Democracy 8A/1-2-2011), makes effort to improve incentives in order to become attractive to a larger proportion of entrepreneurs and with the ultimate goal of reversing the negative investment climate that passes the country and create real growth. The investment law is necessary to promote investment, especially in sectors and activities that will bring real growth, new jobs and will use modern technology and innovation, for the production of quality products and services (Papanaoum, 2012, http://www.tax-profit.gr).

The strategic objectives for the enhancement of openness must be (a) continuous improvement of the international competitiveness of the country, (b) giving vision and strategy for extroversion, (c) the establishment of a comprehensive strategy involving the presence of the country abroad, (d) changing structure of inverted enterprises direct investment and finally (e) improving the attractiveness of the country by foreign investors (Chletsos, 2008). 
Extroversion is necessary to be strengthened and become a common practice for both large companies and small and medium-sized enterprises. A series of measures such as increasing productive investment, quality of products, their standardization, interlinking of Greece with the international production systems and the upgrading of manpower need to be undertaken (Aggelopoulos, 2007). It is necessary to simplify business processes and to reduce bureaucracy, for the State to become more competitive, to stabilize the fiscal system, which must become more objective and consistent. Also, evaluate the laws regarding to the competitiveness of enterprises (Ioannidis, 2007).

A proposal is the recommendation of the Secretariat, the competent Ministry Outreach. The secretariat will undertake the responsibilities relating to the collection and management of available resources for extroversion. In this way, the demands will be placed in the Centre of the recovery of the Greek economy. The institution that undertakes these activities today is the General Secretariat for investments and development, which promotes the financing programs that support the development of the country (http://www.ggea.gr). The mixture of economic policy that Greece must concentrate on is creative entrepreneurship and extroverted activities (Argitis, 2012).

\section{Conclusion}

It is necessary to establish a State, which will meet the demands of the globalized society and the participation of Greece in the enlarged EU. To reinforce the extroversion the promotion of Greece must contribute in international transport hub, commercial activities and services of quality to serve an expanding European market and will offer efficient interconnection between Europe and the emerging markets (Tsapakidis, 2012; Balyrakis, 2008).

\section{References}

Aggelopoulos, K, (2007). "The demands of business: development and survival Factor." Liberal Update, vol. 32 (72 - 79). Argitis, G.. (2012). Bankruptcy and financial crisis. Failure and collapse of the Greek model of capitalism, Athens : Alexandria. Balyrakis, S., (2008). Conclusions Symposium organized by the Foundation for Mediterranean Studies, Athens.

Chletsos, M., (2008). Competitiveness - Entrepreneurship - Extroversion of Greek economy, Athens : Ministry of national education and religious affairs.

Christodoulakis, A., (2011). "McKinsey : Proposed development model with 500,000 jobs - the study of the company presented by the BSE", The Tribune, 5/9/2011, on the website http://www.tovima.gr/finance/article/?aid=418022, accessed on 11/11/2012.

Commercial Bank (2011) Prospectus for the listing of shares of the company FOLLI FOLLIE GROUP in SE, Athens : Commercial Bank. Damoylianou, C., (2012). «Practice new Opportunity in another country in Europe», Kathimerini, 2/9/2012.

Drosos, P., (2007). "Greek exports as extroversion factor", Liberal Focus, V. 32 (56 - 62).

Drosos, P,. (2006). "The Greek strategy for exports". Liberal Focus, V. 27 (62 - 67 ).

Dynning, J., (1993). The globalization of business: The challenge of the 1980s, NY : Routledge.

Fordham, Fr., ( $\_$. What really Jung said, Athens : Gull.

Fountoulis, G., (2012). "Outlet for Greek wines", Kathimerini - The Economist, vol. 104, October (36).

INE - GSEE, (2010), The Greek economy and employment. Annual report, Athens : INE - GSEE.

Ioannidis, A., (2007). "The demands of the economy and the new role of the State." Liberal Update, vol. 32 (87 - 92).

Ioannidis, F., and Chatzihristou, F., (2012). Entrepreneurship in Greece 2010 - 2011 - the "small" entrepreneurship in a time of crisis, Athens: Foundation for Economic and Industrial Research.

Korres, G., and Chionis, D., (2003). Greek economy - Economic politics and analysis of main aggregates, Athens : Stamoulis.

Liargovas, P., (2010). Contemporary themes of Greek and international economy, Athens : Stamoulis.

Mavrogiorgou, El. (2012), The Erasmus sectoral program - the Erasmus-practice new skills in the workplace, keynote speaker at the European educational program "Lifelong learning", The NHRF, 16/10/2012.

Papanaoum, El., (2012). "New investment law 3908/2011: the last hope of the country's development (?)", The Tribune, 10/24/2012.

Pournarakis, A., and Chatzikonstantinou, G. (2011). Economic principles - Macroeconomic and Microeconomic, 3rd Edition, Athens : Wisdom.

Sklias, P., and Galatsidas, G., (2010). "The Political Economy of the Greek crisis: Roots, Causes and Perspectives for Sustainable Development», Middle Eastern Finance and Economics, Issue 7.

Stergiou, C., (2007). "The vision and the practical dimension of openness". Liberal Update, vol. 32 (93 - 101).

Tsapakidis, C., (2012). "Interview with Chinese Ambassador Du Qiwen", Kathimerini - The Economist, vol. 104, April (34 - 35).

Tsoulfidis, I., (2011). Economic history of Greece, 2nd Edition, Thessaloniki : University of Macedonia.

World Bank IFC Report (2012). Doing Business Smarter regulations for 2013 : Small and medium-size enterprises, Washington : The World Bank.

http://www.statistics.gr/portal/page/portal/ESYE/BUCKET/A0902/PressReleases/A0902_SFC02_DT_MM_09_2012_01_E_GR.pdf (accessed on 10/11/2012).

http://www.safran.gr/( accessed on 7/12/2012).

http://www.follifollie.com/HOME/1_2.html (accessed on 7/12/2012). 
http://www.vaeni-naoussa.gr/( accessed on 7/12/2012).

http://www.helixfar.gr/el/( accessed on 7/12/2012).

http://www.espa.gr/el/Pages/ProclamationsFS.aspx?item=1525 (accessed on 7/12/2012).

http://newsedu.gr/index.php?option=com_content\&view=article\&id=1902:-746-q-iiq\&catid=85:2011-09-09-13-42-41\&Itemid=50 (accessed on 7/12/2012).

http://www.tovima.gr/finance/article/?aid=453729 (accessed on 7/12/2012).

http://www.skai.gr/news/finance/article/2155 (accessed on 11/11/2012).

http://www.skai.gr/news/finance/article/2155 (accessed on 11/11/2012).

http://www.pse.gr/node/41 (accessed on 10/11/2012).

http://www.tovima.gr/finance/article/?aid=418022 (accessed on 11/11/2012).

http://repository.edulll.gr/edulll/retrieve/4619/1315.pdf (accessed on 11/11/2012).

http://www.dig\% CE\% BC\% CE\% BF\% CE\% B9/(accessed on 11/11/2012).

http://www.bms-sa.gr/ellhninkh-exwstrefeia.aspx (accessed on 11/11/2012).

http://www.antagonistikotita.gr/greek/news.asp?id=326 (accessed on 11/11/2012).

www.ypoian.gr (accessed on 11/11/2012).

www.antagonistikotita.gr (was on 11/11/2012).

www.efepae.gr (accessed on 11/11/2012).

www.espa.gr (accessed on 11/11/2012).

www.ependyseis.gr/mis (accessed on 11/11/2012).

www.ggb.gr (accessed on 11/11/2012).

http://www.taxprofit.gr

http://europa.eu/rapid/pressReleasesAction.do?reference=IP/12/83\&format=HTML\&aged= (accessed on 13/8/2012).

http://compus.uom.gr/erasmus/?q=el/general (accessed on 13/8/2012).

http://www.olakala.gr/oikonomia/2269-i-politimi-axia-tis-exostrefeias.html (accessed on 13/8/2012).

http://espa.com.gr/protasei_exostrefeias/( accessed on 13/8/2012).

http://tvxs.gr/news

http://www.statistics.gr/portal/page/portal/ESYE (accessed on 17/11/2012).

http://www.dealnews.gr/

http://www.ggb.gr

http://news.kathimerini.gr/4dcgi/_w_articles_economyepix_100012_04/12/2011_464956 (was on 17/11/2012).

http://boraeinai.blogspot.gr/2011/12/e_08.html (was on 18/11/2012).

http://www.safran.gr/trading.asp (was on 18/11/2012).

http://www.pta-pdm-smartplus.gr/assets/profile-innofin-anko.pdf (accessed on 19/11/2012).

http://www.ggea.gr (was on 19/11/2012).

http://www.palo.gr/cluster/articles/makedonia-nea/27650/?clid=3197913 (accessed on 19/11/2012).

http://www.keosoe.gr/ampeli/deltia.html (accessed on 19/11/2012).

http://www.maknews.gr/index.php?option=com_content\&view=article\&id=7029\%3Avaeni----\&catid=1\%3Aimathia\&ltemid=59 (accessed on 20/11/2012).

http://www.paseges.gr/el/news/120-ayxhsh-stis-exagwges-krasioy-apo-to-Synetaiirsmo-Vaeni-Naoysa (accessed on 2/12/2012).

\section{Annexes}

Table 1 : Greek exports by geographical areas (Jan-Jul) in million $€$.

\begin{tabular}{|l|c|c|c|c|c|}
\hline \multirow{2}{*}{ Region } & \multicolumn{2}{|c|}{ Exports } & \% Change & \multicolumn{2}{c|}{ \% Composition } \\
\cline { 2 - 6 } & $\mathbf{2 0 1 2}$ & $\mathbf{2 0 1 1}$ & $\mathbf{1 2 / 1 1}$ & $\mathbf{2 0 1 2}$ & $\mathbf{2 0 1 1}$ \\
\hline Total & $\mathbf{9 . 8 8 2 , 4}$ & $\mathbf{9 . 5 1 5 , 9}$ & $\mathbf{3 , 9} \%$ & $\mathbf{1 0 0 , 0} \%$ & $\mathbf{1 0 0 , 0} \%$ \\
\hline OECD (29 countries) & $5.576,0$ & $5.717,5$ & $-2,5 \%$ & $56,4 \%$ & $60,1 \%$ \\
\hline E.U. (25) & $5.114,9$ & $5.453,3$ & $-6,2 \%$ & $51,8 \%$ & $57,3 \%$ \\
\hline E.U. (15) & $4.071,6$ & $4.362,4$ & $-6,7 \%$ & $41,2 \%$ & $45,8 \%$ \\
\hline N. America & 548,2 & 397,5 & $37,9 \%$ & $5,5 \%$ & $4,2 \%$ \\
\hline Other Developed Countries & 99,4 & 74,4 & $33,6 \%$ & $1,0 \%$ & $0,8 \%$ \\
\hline Other OECD (except N. Korea) & 510,9 & 468,2 & $9,1 \%$ & $5,2 \%$ & $4,9 \%$ \\
\hline Balkans & $1.673,3$ & $1.583,0$ & $5,7 \%$ & $16,9 \%$ & $16,6 \%$ \\
\hline CIS & 377,5 & 295,5 & $27,8 \%$ & $3,8 \%$ & $3,1 \%$ \\
\hline N. Africa and Middle East & 779,6 & 645,4 & $20,8 \%$ & $7,9 \%$ & $6,8 \%$ \\
\hline African Countries (except N. Africa) & 82,0 & 74,7 & $9,8 \%$ & $0,8 \%$ & $0,8 \%$ \\
\hline Southeast Asia & 191,1 & 145,3 & $31,5 \%$ & $1,9 \%$ & $1,5 \%$ \\
\hline Latin America & 46,4 & 24,8 & $86,7 \%$ & $0,5 \%$ & $0,3 \%$ \\
\hline
\end{tabular}




\begin{tabular}{|l|c|c|c|c|c|}
\hline Other Countries & 459,2 & 353,8 & $29,8 \%$ & $4,6 \%$ & $3,7 \%$ \\
\hline
\end{tabular}

Source : http://www.pse.gr/node/41 (accessed on 10/11/2012).

Table 2: Recent Statistics

\begin{tabular}{|l|l|c|}
\hline \multicolumn{1}{|c|}{ Element } & \multicolumn{1}{c|}{ Period } & Cost \\
\hline Consumer Price Index (Inflation) & Oct. 12/Oct. 11 & 1,6 \\
\hline Harmonized Index of Consumer Prices & Oct. 12/Oct. 11 & 0,9 \\
\hline Gross Domestic Product (Estimates) & $3^{\text {rd } \text { Semester 2012 }}$ & $-7,2$ \\
\hline Unemployment Rate & $2^{\text {nd }}$ Semester 2012 & 23,6 \\
\hline Industrial Production Index & Sep. 12/Sep. 11 & $-7,3$ \\
\hline Turnover Index in Retail Trade & Aug. 12/Aug. 11 & $-8,0$ \\
\hline Producer Price Index in Industry & Sep. 12/Sep. 11 & 5,0 \\
\hline Construction Activity (volume) & Aug. 12/Aug. 11 & $-27,5 \%$ \\
\hline Legal Census Population & 2011 & 9.903 .268 \\
\hline
\end{tabular}

Source: http://www.statistics.gr/portal/page/portal/ESYE (accessed on 17/11/2012). 